\title{
Paraonis fulgens (Annelida: Paraonidae), a new species record for the marine fauna of Turkey
}

\section{Paraonis fulgens (Annelida: Paraonidae), Türkiye deniz faunası için yeni bir tür kaydı}

\section{Deniz Erdoğan Dereli1* $\bullet$ Melih Ertan Çınar²}

${ }^{1}$ Ege University, Faculty of Fisheries, Department of Hydrobiology, 35100 Bornova, Izmir

https://orcid.org/0000-0003-2754-8378

${ }^{2}$ Ege University, Faculty of Fisheries, Department of Hydrobiology, 35100 Bornova, Izmir

https://orcid.org/0000-0002-1802-2801

Erdoğan Dereli, D. \& Çınar, M.E. (2020). Paraonis fulgens (Annelida: Paraonidae), a new species record for the marine fauna of Turkey. Ege Journal of Fisheries and Aquatic Sciences, 37(2), 181-185. DOI: 10.12714/egejfas.37.2.09

Abstract: The present paper deals with the occurrence of Paraonis fulgens on the coast of Turkey. Three specimens of this species were found at $4 \mathrm{~m}$ on sandy mud bottom in İskenderun Bay, north-east Levantine Sea. The morphological and distributional features of the species were given. The present study firstly described a ventral lobe on segments in the family Paraonidae.

Keywords: Polychaeta, Paraonidae, new record, Paraonis, Levantine Sea

Öz: Bu çalışmada, Paraonis fulgens türünün Türkiye kıyılarındaki varlığını ilk kez rapor etmektedir. Bu türe ait 3 birey, İskenderun Körfezi'nde (kuzey-doğu Levanten Denizi) 4 metre derinlikte kumlu çamurlu zeminde tespit edilmiştir. Bu çalışmada, türün morfolojik ve dağılım özellikleri verilmiştir. Bu çalışma Paraonidae familyasında segmentlerde ilk kez bir ventral lop tanımlamıştır.

Anahtar kelimeler: Polychaeta, Paraonidae, yeni kayıt, Paraonis, Levant denizi

\section{INTRODUCTION}

The family Paraonidae Cerruti, 1909 comprises six genera (Aricidea, Cirrophorus, Levinsenia, Paradoneis, Paraonides and Paraonis) and 27 species on the coast of Turkey (Çinar et al., 2014; Erdoğan-Dereli et al., 2017; Erdoğan-Dereli and Çınar, 2019). The genus Aricidea is represented by 11 species, Cirrophorus by 3 species, Levinsenia by 6 species, Paradoneis by 5 species, Paraonides by 1 species and Paraonis by 1 species.

Among these genera, the genus Paraonis has eight species $(P$. amazonica, $P$. dubius, $P$. fulgens, $P$. paucibranchiata, $P$. pygoenigmatica, $P$. strelzovi, $P$. reductus, and $P$. pycnobranchiata) in the world's oceans and three species ( $P$. paucibranchiata, $P$. tenera and $P$. fulgens) in the Mediterranean Sea (Cerruti, 1909; Hartman, 1965; Fauchald, 1972; Blake, 2016; Riberio et al., 2018). In the eastern Mediterranean Sea, two Paraonis species have been reported up to date; $P$. fulgens from Greece (Faulwetter et al., 2017) and $P$. tenera from Turkey (Çinar et al., 2014). However, the later species has accepted as nomen inquirendum by Strelzov (1979), so the validity of this species requires further investigation.
The present study newly reports the presence of $P$. fulgens from the coast of Turkey, and provides the morphological and ecological features of the species.

\section{MATERIAL AND METHODS}

The specimens of Paraonis fulgens were collected at $4 \mathrm{~m}$ depth on sandy mud bottom near the crude oil jetty of BaküTbilisi-Ceyhan pipeline (BTC) in İskenderun Bay (Yumurtalık) (Figure 1). The benthic sample at the station was taken by a Van-Veen Grab (sampling an area of $0.1 \mathrm{~m}^{2}$ ) and sieved through $0.5 \mathrm{~mm}$ mesh in the field. The retained material put into a plastic jar, and fixed with $4 \%$ formaldehyde and seawater solution. The material was then transferred to the Ege University Benthology Laboratory and washed on a $0.5 \mathrm{~mm}$ mesh with tap water. The material was sorted under a stereomicroscope and the specimens were preserved in $70 \%$ ethanol. The measurements of the specimens of $P$. fulgens (length, wide, etc.) were made by using an ocular micrometer. Photographs of the specimens were taken with a digital camera (Olympus OM-D E-M5 Mirrorless), mounted on stereo- and light microscopes. The specimens of $P$. fulgens were deposited at the Museum of Faculty of Fisheries (ESFM), Ege University, Izmir, Turkey. 


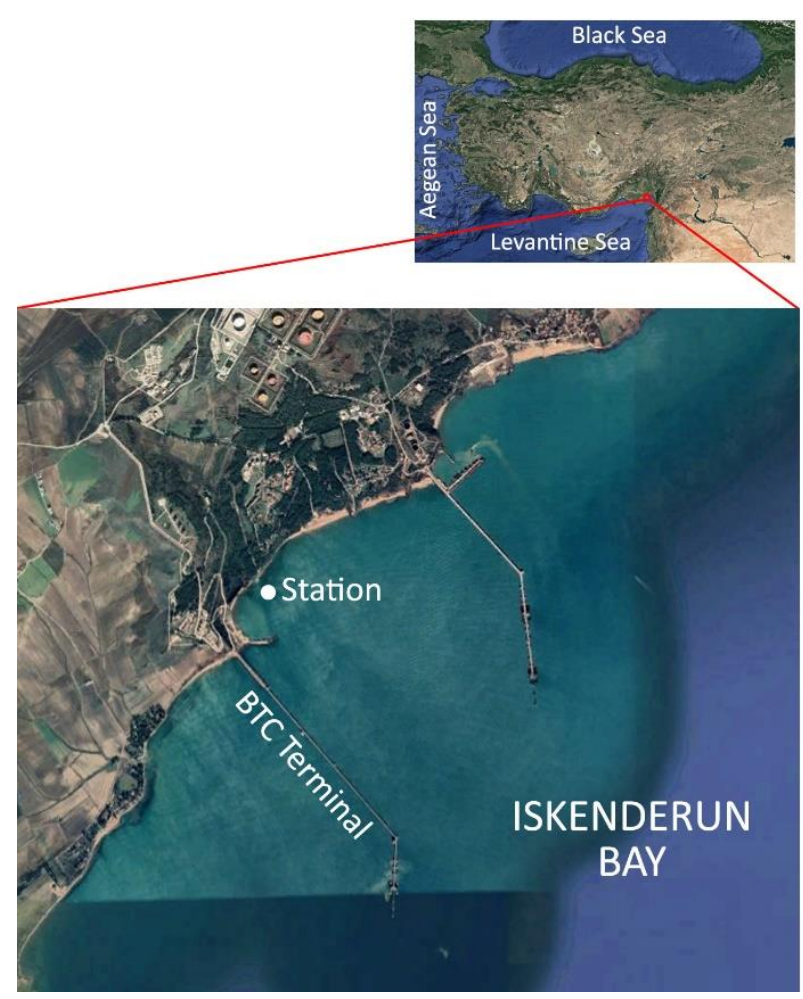

Figure 1. Map of the studied area (Google Earth, 10.12.2019)

\section{RESULTS}

\section{Phylum: Annelida Lamarck, 1809 Classis: Polychaeta Grube, 1850 Family: Paraonidae Cerruti, 1909 Genus: Paraonis Grube, 1873}

\begin{abstract}
Paraonis fulgens (Levinsen, 1884) (Figure 2, 3)
Aonides fulgens Levinsen, 1884:105-106

Levinsenia fulgens, Mesnil and Caullery, 1898:128-136; 138, Plate 6-Fig. 1-9.

Paraonis fulgens, Cerruti, 1909:468-469, Figure H1, 2; Fauvel, 1927: 71-72, Figure 24G-L; Pettibone, 1963: 302, Figure 79E-F; Strelzov, 1979: 55-59, Figure 20; Gaston, 1984: 2-47, Figure 2-45, 2-46; Castelli, 1985: 268-270, Figure 2; Hartmann-Schröder, 1996: 387-388, Figure 184; Aguirrezabalaga, 2012: 272-274, Figure 124.
\end{abstract}

Material examined. ESFM-POL/2015-268, 30 June 2015, station $3,36^{\circ} 52^{\prime} 23^{\prime \prime} \mathrm{N}-35^{\circ} 55^{\prime} 25^{\prime \prime} \mathrm{E}, 4 \mathrm{~m}$, sandy mud, 3 specimens.

Description. Largest specimen complete, $4.06 \mathrm{~mm}$ long, $0.06 \mathrm{~mm}$ wide at chaetiger 10 , with 90 chaetigers. Color in alcohol usually dull white or yellowish; red speckles present between notopodium and neuropodium, from middle branchial region to pygidium (Figures $2 A ; 3 D$ ). Body thin, spiralled; first three chaetigers distinctly smaller and thinner; branchial chaetigers moniliform shaped; posterior region relatively thick, tapering to pygidium (Figures $2 A-D$ ). A dense ciliary band present on mid-dorsal transversal line of each prebranchial and branchial chaetigers (Figure 3E); ciliary bands absent from ventral side. Prostomium triangular, anterior region distinctly elongated with eversible palpode, much longer than wide (length/width: 1.16); a pair of cheek organs located posteriolaterally on prostomium; a pair of crystalline lenses located anterio-laterally near intradermal eyes (Figures 2C, E). First ciliary band (cb1) located on anterior part of prostomium, just above eyes; second ciliary band (cb2) located laterally above nuchal organs; and third ciliary band (cb3) commencing lateral sides of prostomium extending to anterior margin of chaetiger 1 (Figure 3A).

A pair of nuchal organs as deep, narrow slits placed dorsolaterally on posterior part of prostomium, without pigmentation (Figure 2C). Mouth with 2 lips; one placed anteriorly and other placed posteriorly, extending to middle region of chaetiger 1. Branchiae 21 pairs, beginning on chaetiger 4 in all specimens; shorter than segment width, last three pairs shorter than others, last pair rudimentary; $167 \mu \mathrm{m}$ long in anterior region, $197 \mu \mathrm{m}$ long in middle region, $127 \mu \mathrm{m}$ long in posterior region. Branchiae flattened, broadly foliaceous; posterior part of base asymmetrically enlarged towards posterior region with elongated round tips, with dense ciliary bands (Figures 2B, C; $3 \mathrm{~B})$; Dorsal and ventral rami of parapodia quite distinct in prebranchial and branchial regions (Figures 3B, C, F), not distinct in posterior region. Interramal lobes absent. Notopodial papillae absent. Notopodial postchaetal lobes absent in first two chaetigers, commencing on chaetiger 3 , short and cirriform; longer, thin and digitiform on anterior region of branchial region; long, weakly thick with asymmetrical enlargement on base over ventral side of middle and posterior chaetigers of branchial region; long, thin and filiform on posterior region (Figures 2C; 3B-D). Neuropodial lobes commencing from chaetiger 4 extending to chaetiger 21, as rudimentary ridges (Figure $3 \mathrm{C}$ ). Ventral lobe occurring between chaetigers 12 and 14, small, rounded, located near posterior margin of segments (Figure 3F).

Three types of chaeta: limbate, capillary and modified neurochaeta. Notopodia of anterior region carrying 6-15 limbate chaeta; those of middle region carrying 10-17 capillary chaeta; those of posterior region carrying 4-8 capillary chaeta. Neuropodia of anterior region carrying 7-18 limbate chaeta; neuropodia of middle region carrying 8-14 capillary chaeta; those of posterior region carrying 18-30 capillary chaeta and 2 modified neurochaeta. Limbate chaeta (with hirsute only on chaetigers 1-6, without hirsute on 7-21 chaetigers) present on both notopodia (chaetal length: $174 \mu \mathrm{m}$, in 3 rows) and neuropodia (chaetal length: $165 \mu \mathrm{m}$, in 3 rows) of chaetigers 1 21 (Figure 3I). Notopodial and neuropodial capillary chaeta from chaetiger 22 to pygidium, two rows on notopodia in middle region and one row on notopodia in posterior region; 2 rows on neuropodia in middle and posterior regions; $264 \mu \mathrm{m}$ long in middle region and $243 \mu \mathrm{m}$ long in posterior region. Modified neurochaeta commencing from chaetiger 48 to pygidium, numbering 2 in all chaetigers; $46 \mu \mathrm{m}$ long; hook shaped, subterminally strongly curved, with a distinct hood; arista absent (Figures 3G, H).

Pygidium rounded with 3 anal cirri; two ventro-lateral cirri (thin, long, $50 \mu \mathrm{m}$ long) and a mid-ventral cirrus (thin, short, 30 $\mu \mathrm{m}$ long); anal aperture on dorsal side (Figure 3J). 

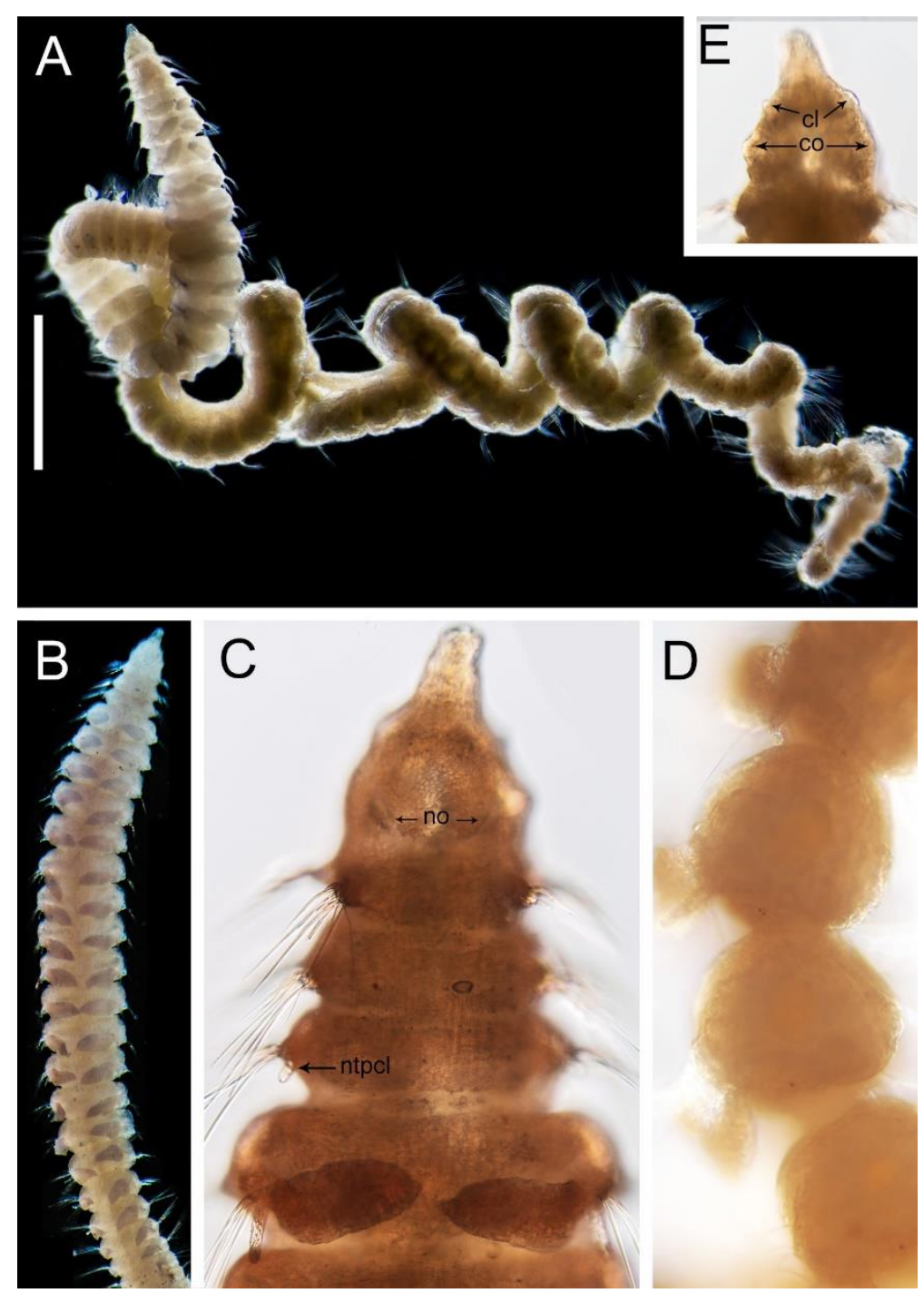

Figure 2. Paraonis fulgens ESFM-POL/2015-268. A, General view of specimen; B, Anterio-dorsal view; C, Anterio-dorsal view of first chaetigers; $D$, Lateral view of chaetigers in the branchial region; E, Dorsal view of prostomium. Abbreviations: cl, crystalline lens; $c 0$, cheek organ; no, nuchal organs; ntpcl, notopodial postchaetal lobe. Scale bars: A, $375 \mu \mathrm{m} ; \mathrm{B}, 673 \mu \mathrm{m} ; \mathrm{C}, 114 \mu \mathrm{m} ; \mathrm{D}, 67 \mu \mathrm{m} ; \mathrm{E}, 190 \mu \mathrm{m}$.

Reproduction. All specimens of $P$. fulgens collected in June from İskenderun Bay were male; sperms were like white masses, present from the chaetigers $30-32$ to the preanal region. According to the previous studies, the specimens with eggs were reported in May from Isefjord, Denmark (Rasmussen, 1973) and in August from New England, USA (Pettibone, 1963). Rasmussen (1973) reported that the number of eggs in each segment were 3-4 and that eggs had a diameter of ca. $200 \mu \mathrm{m}$. Strelzov (1979) indicated that the number of eggs in segments (present from the chaetiger 34) reached up to 4 and the egg diameter reached up to $90 \mu \mathrm{m}$. Like the present observation, Mesnil and Caullery (1898) also stated that the formation of sperm gametes was like masses, not like packages.

Habitat and Distribution. Paraonis fulgens is a shallowwater species, previously reported on soft bottom between 5 and $13 \mathrm{~m}$ depth from the North Sea (Levinsen, 1884), the
English Channel (Fauvel, 1927; Dauvin and Cabioch, 1988), the eastern (Mesnil and Caullery, 1898) and western (Gaston 1984, Pettibone, 1963) Atlantic Ocean, the eastern (Faulwetter et al.,2017) and western Mediterranean Sea (Cerutti, 1909, Castelli, 1988), and the Black Sea (Kurt-Şahin and Çınar 2012).

\section{DISCUSSION}

Paraonis fulgens is mainly characterized by having a triangular prostomium with the elongated anterior margin; crystalline lens located anterio-laterally on the prostomium; first three chaetigers distinctly smaller and thinner than those in the rest of the body; very distinct ventral and dorsal rami; a moniliform body shape in the branchial region; asymmetrical enlargement on the base of branchiae towards posterior region and modified neurochaeta as curved hooks (no dentation). 
The cheek organs and crystalline lenses in the prostomium of Paraonis fulgens, which were first mentioned by Mesnil and Caullery (1898), were also observed in the Levantine Sea's specimens (Figure 2E). Strelzov (1979) stated that the crystalline lenses did not exist on the specimens that he examined. However, as these lenses are located intradermally, they might be easily escaped from researcher's attentions. The cheek organ was firstly observed in some Levinsenia species by Strelzov (1979). He described that the Paraonis genus had no cheek organs. However, the present study confirmed the presence of the cheek organs in $P$. fulgens, which might be retractile or difficult to detect in contracted specimens due to fixation.

The present study firstly described a ventral lobe on the posterior parts of segments in the family Paraonidae. However, this character was also observed in some Aricidea species (paper in preparation). The function of this lobe is unknown.

In the Levantine Sea's specimens of Paraonis fulgens, the modified neurochaeta did not bear any arista on the concave side. The lack of arista on the chaeta was also mentioned by Mesnil and Caullery (1898), Cerruti (1909), Fauvel (1927), Pettibone (1963) and (Strelzov, 1979). However, Castelli (1985) reported a fragile arista on the modified neurochaeta on the specimens collected from the Tuscan coasts (western Mediteranean).
Strelzov (1979) observed four ciliary bands on the prostomium of Paraonis fulgens, whereas we observed only three ciliary bands on the prostomium (Figure $3 \mathrm{~A}$ ). The ciliary band 2 found in the present study seems to be similar to nnacb (nuchal organ associated ciliary band) that was described for Paradoneis species by Erdoğan-Dereli and Çınar (2019), but at this stage it is not clear if the ciliary band 2 is associated with the nuchal organ.

Hartmann-Schröder (1996) reported that the notopodial postchaetal lobes were small on the first two chaetigers, short finger-shaped on the chaetiger 3 and were getting longer gradually towards the branchial region. She might have misinterpreted the ridges on the first two chaetigers as notopodial lobes or the specimens she examined might belong to an undescribed species. Unlike the other descriptions of the species, Fauvel (1927) stated that $P$. fulgens had no neuropodial postchaetal lobes.

\section{ACKNOWLEDGMENTS}

Authors are indebted to colleagues in the Benthology Laboratory of Ege University for their help in collecting and sorting the benthic material.
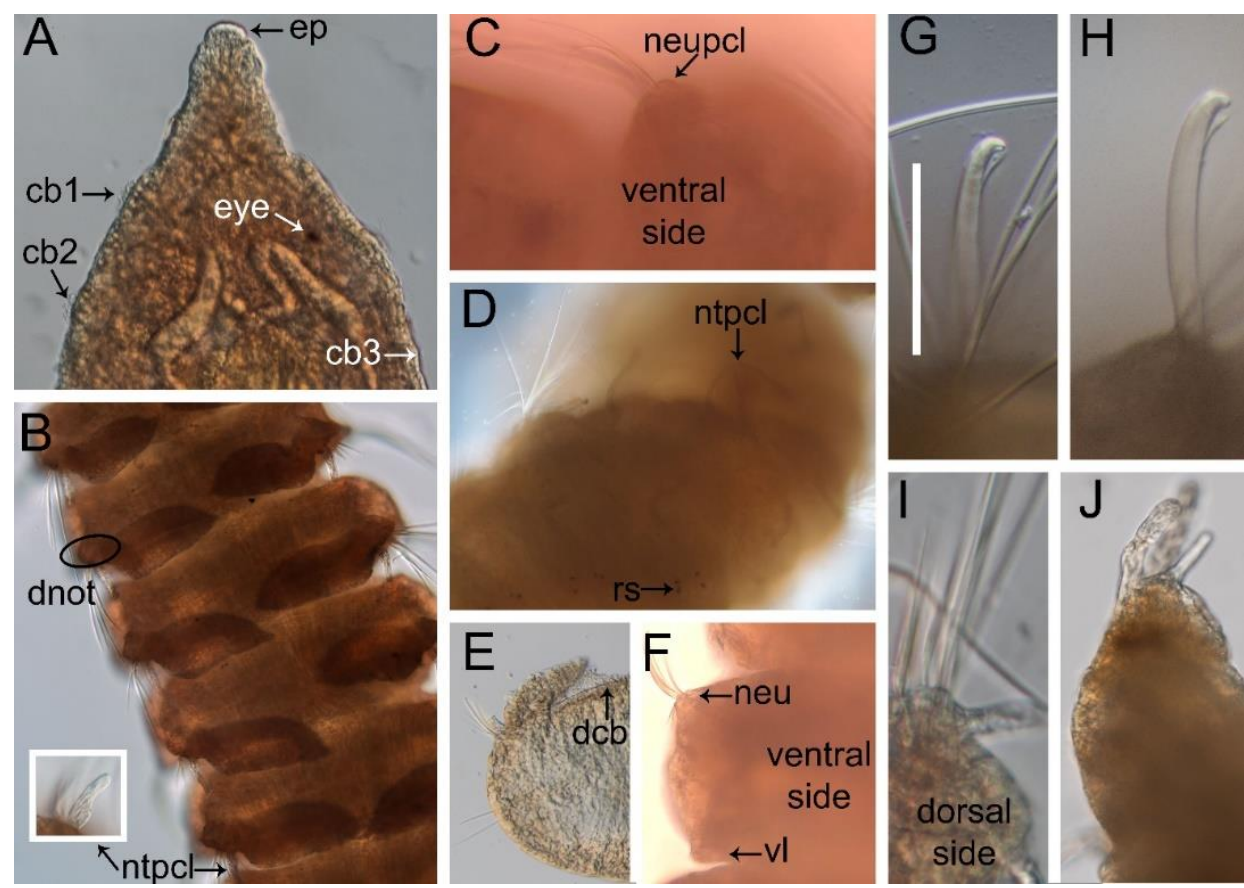

Figure 3. Paraonis fulgens ESFM-POL/2015-268. A, Dorsal view of prostomium; B, Dorsal view of branchial region, ellipse shape indicated the distinct dorsal rami; $C$, Ventral view of chaetiger 3 ; D, Dorsal view from posterior region; $E$, Cross section of chaetiger 5 ; $F$, Ventral view of chaetiger 12; G, Modified neurochaeta from chaetiger 52; H, Modified neurochaeta from chaetiger 67; I, Limbate chaeta from chaetiger 3; J, Lateral view of pygidium. Abbreviations: $c b 1$, ciliary band $1 ; \mathrm{cb} 2$, ciliary band 2; $\mathrm{cb} 3$, ciliary band 3; dcb, dorsal ciliary band; dnot, distinct notopodium; ep, eversible palpode; neu, neuropodium; neupcl, neuropodial postchaetal lobe; ntpcl, notopodial postchaetal lobe; rs, red spots; vl, ventral lobe. Scale bars: A, $100 \mu \mathrm{m} ; \mathrm{B}, 87.5 \mu \mathrm{m}$; C, $25 \mu \mathrm{m} ; \mathrm{D}, 190 \mu \mathrm{m}$; E, $224 \mu \mathrm{m} ; \mathrm{F}, 81 \mu \mathrm{m} ; \mathrm{G}, 31 \mu \mathrm{m} ; \mathrm{H}, 34 \mu \mathrm{m} ; \mathrm{I}, 37 \mu \mathrm{m} ; \mathrm{J}, 65 \mu \mathrm{m}$. 


\section{REFERENCES}

Aguirrezabalaga, F. (2012). Familia Paraonidae Cerruti, 1909. In: Parapar, J., Alós, C., Núñez, J., Moreira, J., López, E., Aguirrezabalaga, F., Besteiro, C. \& Martínez, A. (Eds.), Annelida Polychaeta III. Fauna Ibérica. Vol. 36. Museo Nacional de Ciencias Naturales, CSIC, Madrid, 160-272.

Blake, J.A. (2016). Paraonidae Cerruti, 1909. In: Westheide, Wilfried; Purschke, Günter (eds). Handbook of Zoology Online, Annelida: Polychaetes Edition. pp. ,29, De Gruyter, Berlin.

Castelli, A. (1985). Paraonidae (Annelida, Polychaeta) des fonds meubles intralittoraux des cotes toscanes. Cahiers de Biologie Marine, 26:267279.

Castelli, A. (1988). Censimento dei Policheti dei Mari Italiani: Paraonidae Cerruti, 1909. Atti della Società Toscana di Scienze Naturali Memorie 94: 319-340.

Cerruti, A. (1909). Contributo all'anatomia, biologia e sistematica delle Paraonidae (Levinsenidae) con particolare riguardo alle specie del golfo di Napoli. Mittheilungen aus der Zoologischen Station zu Neapel, 19:459512.

Çinar, M.E. (2005). Polychaetes from the Coast of northern Cyprus (eastern Mediterranean Sea), with two new records for the Mediterranean Sea. Cahiers de Biologie Marine, 46:143-161 pp.

Çinar M.E. \& Dagli E. (2013). Polychaetes (Annelida: Polychaeta) from the Aegean and Levantine coasts of Turkey, with descriptions of two new species. Journal of Natural History, 47:13-14, 911-947. DOI: 10.1080/00222933.2012.752543

Çinar, M.E., Dağli, E. \& Kurt-Şahin, G. (2014). Checklist of Annelida from the coasts of Turkey. Turkish Journal of Zoology, 38, 734-764. DOI: 10.3906/zoo-1405-72

Çinar, M.E., Katağan, T., Öztürk, B., Dağı, E., Açık, Ş., Bitlis-Bakır, B., Bakır, K. \& Doğan, A. (2012). Spatio-temporal distributions of zoobenthos in Mersin Bay (Levantine Sea, eastern Mediterranean) and the importance of alien species in benthic communities. Marine Biology Research, 8:954968. DOI: 10.1080/17451000.2012.706305

Dauvin, J.C. \& Cabioch, L. (1988). New species for the list of marine fauna from Roscoff: Amphipod (Siphonoecetes striatus) and polychaete Paraonidae, and spatial distribution of Echinocardium pennatifidum. Nouvelles especes pour l'inventaire de la faune marine de Roscoffcrustaces amphipodes: Siphonoecetes striatus Myers et McGrath et annelides polychetes Paraonidae et nouvelles donnees sur la repartition du spatangide Echinocardium pennatifidum Norman. Cahiers de Biologie Marine, 29(2): 215-219.

Erdoğan-Dereli, D. \& Çınar M.E. (2019). The genus Paradoneis (Annelida: Paraonidae) from the Sea of Marmara, with descriptions of two new species. Zootaxa, 4686 (4), 465-496. DOI: 10.11646/zootaxa.4686.4.2

Erdoğan-Dereli, D., Çınar, M.E. \& Dağlı, E. (2017). Cirrophorus species (Annelida: Polychaeta: Paraonidae) in the Sea of Marmara, with description of a new species. Zootaxa, 4347 (1), 137-150. DOI: 10.11646/zootaxa.4347.1.8

Ergen, Z., Cinar, M.E. \& Unsal M. (1998). Polychaetes from the Manavgat River Delta (Turkish Mediterranean coast). Rapports et procés-verbaux des réunions Commission internationale pour l'exploration scientifique de la Mer Méditerranée, 35:536-537.
Fauchald, K. (1972). Benthic polychaetous annelids from deep water off western Mexico and adjacent areas in the Eastern Pacific Ocean. Allan Hancock Monographs in Marine Biology. 7: 1-575.

DOI: 10.1080/00364827.1972.10411211

Faulwetter S., Simboura N., Katsiaras N., Chatzigeorgiou G. \& Arvanitidis C. (2017). Polychaetes of Greece: an updated and annotated checklist. Biodiversity Data Journal 5: e20997. DOI:10.3897/BDJ.5.e20997

Fauvel, P. (1927). Polychètes sédentaires. Addenda aux errantes, Arachiannélides, Myzostomaires. Faune de France, Paul Lechevalier. Paris, 16, 494 p. DOI: $10.1038 / 113528$ B0

Gaston G.R. (1984). Paraonidae. In: Uebelacker M, Jonhson PG, Vittor B (Eds) Taxonomic guide to the polychaetes of the northern Gulf of Mexico 1(2). Barry A Vittor and Associates, Inc., Louisiana, 1-53. DOI: $10.5962 /$ bhl.title.4035

Hartman, O. (1965). Deep-water benthic polychaetous annelids off New England to Bermuda and other North Atlantic areas. Occasional Papers of the Allan Hancock Foundation. 28: 1-384.

Hartmann-Schröder, G. (1996). Annelida, Borstenwürmer, Polychaeta [Annelida, bristleworms, Polychaeta]. 2nd revised ed. The fauna of Germany and adjacent seas with their characteristics and ecology, 58. Gustav Fischer: Jena, Germany, 58, 648 p.

Kurt-Sahin, G. \& Cinar, M.E. (2012). A check-list of polychaete species (Annelida: Polychaeta) from the Black Sea. Journal of the Black Sea/ Mediterranean Environment, 18:10-48 pp.

Levinsen, G.M.R. (1884). Systematisk-geografisk Oversigt over de nordiske Annulata, Gephyrea, Chaetognathi og Balanoglossi. Videnskabelige Meddelelser fra den naturhistoriske Forening i Kjöbenhavn, 45:92-350. DOI: 10.5962/bhl.title.16117

Mesnil, F. \& Caullery, M., 1898, Études de morphologie externe chez les annélides, IV. La famille nouvelle des Leviséniens. Révision des Ariciens - affinités des deux familles, Les Apistobranchiens. Bulletin Scientifique de la France et de la Belgique, 31:126-151.

Mutlu, E., Çinar, M.E. \& Ergev, M.B., 2010, Distribution of softbottom polychaetes of the Levantine coast of Turkey, eastern Mediterranean Sea. Journal of Marine Systems, 79:23-35. DOI: 10.1016/j.jmarsys.2009.06.003

Pettibone, M.H. (1963). Marine polychaete worms of the New England region, I. Aphroditidae through Trochochaetidae. Bulletin of the United States National Museum, 227:1-356. DOI:10.5479/si.03629236.227.1

Rasmussen, E. (1973). Systematics and ecology of the Isefjord marine fauna (Denmark). Ophelia. 11(1): 1-507. DOI: 10.1080/00785326.1973.10430115

Ribeiro, R.P., Alves P.R.; Almeida Z.S. \& Ruta, C. (2018). A new species of Paraonis and an annotated checklist of polychaetes from mangroves of the Brazilian Amazon Coast (Annelida, Paraonidae). ZooKeys. 740: 1-34. DOI: $10.3897 /$ zookeys.740.14640

Strelzov, V.E. (1979). Polychaete Worms of the Family Paraonidae Cerruti, 1909 (Polychaeta, Sedentaria). Amerind Publishing Co., for The Smithsonian Institution \& The National Science Foundation, New Delhi, 212 pp. [English translation from Russian] 